\title{
Chemistry Education in Bosnia and Herzegovina
}

Meliha Zejnilagić-HajRić ${ }^{\star 1}$ AND Ines Nuić ${ }^{2}$

$\propto$ In this paper, the education system in Bosnia and Herzegovina is presented in the light of current state-level legislation, with an emphasis on chemistry education at the primary, secondary and tertiary level. The consequences of the last war in our country still persist and are visible in many aspects of everyday life, including the education system, thus limiting the efforts of education professionals to follow international trends in education. There are three valid curricula for primary education at the national level, each of which differs in the national group of school subjects. Teaching methods are common for all three curricula and are mainly teacher-oriented. The situation is similar with regard to secondary education. Study programmes at the university level are organised in accordance with the Bologna principles. The programmes are made by the universities themselves and approved by the corresponding ministry of education. Chemical education research in Bosnia and Herzegovina is mainly conducted at the University of Sarajevo. It deals with (1) the problems of experimental work in chemistry teaching, resulting in more than 60 experiments optimised for primary and secondary school, (2) integrating the knowledge of chemistry, physics and physical chemistry for university students, with regard to students' difficulties observed during university courses and potential solutions, and (3) the effectiveness of web-based learning material in primary school chemistry for the integration of macroscopic and submicroscopic levels. For the purpose of this paper, official documents for primary, secondary and higher education have been used.

Keywords: chemistry education, Bosnia and Herzegovina, primary school, secondary school, higher education

$1{ }^{*}$ Corresponding Author. Faculty of Science, University of Sarajevo, Bosnia and Herzegovina; mzejnilagic@yahoo.com.

2 Faculty of Science, University of Sarajevo, Bosnia and Herzegovina. 


\section{Kemijsko izobraževanje v Bosni in Hercegovini}

Meliha Zejnilagić-HajRić in Ines Nuić

$\propto$ V prispevku je predstavljen izobraževalni sistem v Bosni in Hercegovini $z$ vidika veljavne državne zakonodaje, s poudarkom na kemijskem izobraževanju na osnovnošolski, srednješolski in na univerzitetni ravni. Posledice zadnje vojne še vztrajajo in so opazne v vseh vidikih vsakdanjega življenja, vključno z izobraževalnim sistemom, v katerem se kaže omejevanje prizadevanj strokovnjakov s področja izobraževanja, da sledijo mednarodnim smernicam v izobraževanju. Na nacionalni ravni obstajajo trije veljavni kurikulumi za osnovnošolsko izobraževanje; vsak izmed njih se razlikuje v naboru šolskih predmetov. Metode poučevanja so skupne vsem trem kurikulumom in so večinoma osredinjene na učitelja. V srednješolskem izobraževanju je situacija podobna. Na univerzitetni ravni pa so študijski programi oblikovani skladno z bolonjskimi načeli. Programe oblikujejo univerze same, potrdi pa jih ministrstvo, pristojno za izobraževanje. Raziskovanje na področju kemijskega izobraževanja v Bosni in Hercegovini v največji meri poteka na Univerzi v Sarajevu. Ukvarja se: 1) s problemi eksperimentalnega dela v poučevanju kemije; 2) z integracijo znanja kemije, fizike in fizikalne kemije na osnovi težave študentov, ki so zaznane med študijem; 3) z učinkovitostjo spletnih učnih gradiv za poučevanje kemije v osnovni šoli, ki integrira makro- in submikroskopsko raven predstavitev kemijskih pojmov. Za potrebe prispevka so bili v raziskavi uporabljeni uradni dokumenti za osnovno-, srednje- in za visokošolsko izobraževanje.

Ključne besede: kemijsko izobraževanje, Bosna in Hercegovina, osnovna šola, srednja šola, visokošolsko izobraževanje 


\section{Introduction}

Before exploring the background of the development of chemistry education, we provide a brief overview of the political and demographic contexts of education in our country.

Bosnia and Herzegovina (informal, Bosnia) was part of the former Yugoslavia (Socialist Federal Republic of Yugoslavia, SFRY) from 1943 to 1992. However, its beginnings as an independent kingdom date back to the Middle Ages (Radušić et al., 2010), while its territory has been inhabited since Neolithic times (Malcolm, 1994). The country's political and cultural history is unique in Europe: the Roman Empire, the Ottomans and the Austro-Hungarians, as well as the religions of Roman Catholicism, Eastern Orthodoxy, Islam and Judaism have combined and overlapped (Malcolm, 1994).

The SFRY disintegrated in the 1990 s and the independence of the Republic of Bosnia and Herzegovina was declared in March 1992. The country was recognised by the United States of America and the European Economic Community in April 1992, and admitted to the UN in May 1992. This was followed by the siege of Sarajevo (1992-1996), where infantry, artillery and mechanised units of the Yugoslav People's Army, in cooperation with the fifth-column armed formations of the Serbian Democratic Party, established complete control over all vital communications. The aggressor closed all access to the city on 6 April 1992. This date had symbolic significance, as it was on 6 April 1945 that Sarajevo was liberated at the end of World War II. The Bosnian war ended in December 1995 after peace negotiations in Dayton, USA.

Since the war, Bosnia and Herzegovina has, according to the Dayton Agreement, consisted of two administrative entities: the Federation of Bosnia and Herzegovina (FB\&H), the Republika Srpska (RS), each with its own constitution, while the self-governing Brčko District is a part of both entities. The FB\&H consists of ten cantons, each with its own government.

There are three official languages in Bosnia and Herzegovina - Bosnian, Croatian and Serbian - and two alphabets, Latin and Cyrillic. According to the population census of 2013 , the total population of $\mathrm{B} \& \mathrm{H}$ is 3.5 million.

\section{The Education System - Basic Structure}

Education in B\&H is organised on four main levels: preschool, primary, secondary and higher education. There are both public and private institutions at all levels of education. Public primary and secondary schools are funded by the government and are not allowed to demand any fees. Textbooks for students 
in a state of social need are usually provided free of charge.

The education system in $\mathrm{B} \& \mathrm{H}$ is a reflection of the internal organisation of the state. At the national level, the Ministry of Civil Affairs and its Sector for Education are responsible for issues related to education. In the Republika Srpska, education is regulated by the relevant ministry through the Republic Education Institute. In the Brčko District, education is regulated by its Department of Education.

In the $\mathrm{FB} \& \mathrm{H}$, jurisdiction has been transferred to the ten cantons and their education institutes or ministries (Table 1), all of which are coordinated by the Federal Ministry of Education and Science (Ibrahimović, 2015). This means that every canton adopts a curriculum for the primary and secondary schools located in its territory.

Table 1

The organisational structure of education authorities in the FB\&H

Ministry of Education, Science, Culture and Sport of Posavina Canton

Ministry of Education, Science, Culture and Sport of Una-Sana Canton

Ministry of Education, Science, Culture and Sport of Tuzla Canton

Ministry of Education, Science, Culture and Sport of Zenica-Doboj Canton

Ministry of Education, Science, Culture and Sport of Central Bosnia Canton

Ministry of Science, Education, Culture and Sport of Canton 10

Ministry of Education, Science and Youth of Sarajevo Canton

Ministry of Education, Youth, Science, Culture and Sport of Bosnian-Podrinje Canton

Ministry of Education, Science, Culture and Sport of Herzegovina-Neretva Canton

Ministry of Education, Science, Culture and Sport of West Herzegovina Canton

\section{Primary Education}

Primary education in B\&H lasts for nine years and comprises levels 1 and 2 of the International Standard Classification of Education - ISCED (UNESCO Institute for Statistics, 2011): Primary Education and Lower Secondary Education. It is compulsory and free for all children. The nine years of primary education are divided into three triads (ages 6-9, 9-12 and 12-15, respectively). Children are enrolled in the $1^{\text {st }}$ grade of primary school at the age of 6 and complete the $9^{\text {th }}$ grade at the age of 15 .

Primary education has recently been extended from eight to nine years, but the reform has not been implemented simultaneously and systematically across the country. In the Republika Srpska, nine-year primary education was 
introduced in 2003/04..$^{3}$ In the FB\&H, different cantons introduced this system in different school years, starting in 2004/05 and ending with the 2009/10 school year (Ministry of Civil Affairs of Bosnia and Herzegovina, 2017).

In 2011, an expert group formed by the Ministry of Education, Science and Youth of Sarajevo Canton made an analysis of the curriculum for nine-year primary education in the Sarajevo Canton (Fejzić et al., 2011). They reported that only formal changes had been made in comparison with eight-year primary education, such as the introduction of an additional year ( $9^{\text {th }}$ grade), while the core of the traditional curriculum, with prescribed content and frontal teaching methods, had been retained. Emphasis is placed on input (teaching content) instead of learning outcomes. In 2016, a revised version of the curriculum for nine-year primary education was prepared in Sarajevo Canton (Ministry of Education, Science and Youth of Sarajevo Canton, 2016). Although there are no significant changes compared to the previous curriculum in terms of teaching content, more attention is paid to the formulation of learning outcomes.

An analysis of the curriculum valid in the Republika Srpska has shown that it is too prescriptive and overly demanding. The lower levels of Bloom's taxonomy are encouraged and the number of clearly formulated learning outcomes with respect to $\mathrm{SMART}^{4}$ criteria is low (Drobac, Hadžić-Krnetić, Mikanović, \& Zečević, 2013).

In $\mathrm{B} \& \mathrm{H}$, there are three valid curricula for primary education, all of which are similar in their structure and teaching methods, with teaching content being prescribed instead of learning outcomes. Certain differences exist in the teaching content within the national group of teaching subjects ${ }^{5}$ (Ibrahimović, 2015). In 2017, a project supported by the organisation USAID and Save the Children in $\mathrm{B} \& \mathrm{H}$ resulted in the Common Core Defined on Learning Outcomes for eight educational domains, both for primary and secondary levels (Agency for PrePrimary, Primary and Secondary Education, 2017). Guidelines for its implementation are also provided (Agency for Pre-Primary, Primary and Secondary Education, 2015), but their implementation in schools is still limited.

One current paradox of the education system is the so-called two schools under one roof, which refers to some primary schools in the FB\&H where students are segregated according to ethnicity: they attend school in the same building, but are physically separated. The original intention was to bring

3 Pupils who finished grades I-VII at the end of the 2002/2003 school year were enrolled in grades III-IX at the beginning of the 2003/2004 school year (Recommendation of the Ministry of Education and Culture of the Republika Srpska for the change to nine-year primary education, from 7 March 2003).

4 SMART: $\mathrm{S}$ - specific, $\mathrm{M}$ - measurable, $\mathrm{A}$ - achievable, $\mathrm{R}$ - realistic, $\mathrm{T}$ - timely.

5 Mother tongue, history, geography and religious education. 
students together after the war, uniting them in one building. However, what was intended to be a temporary solution became highly politicised.

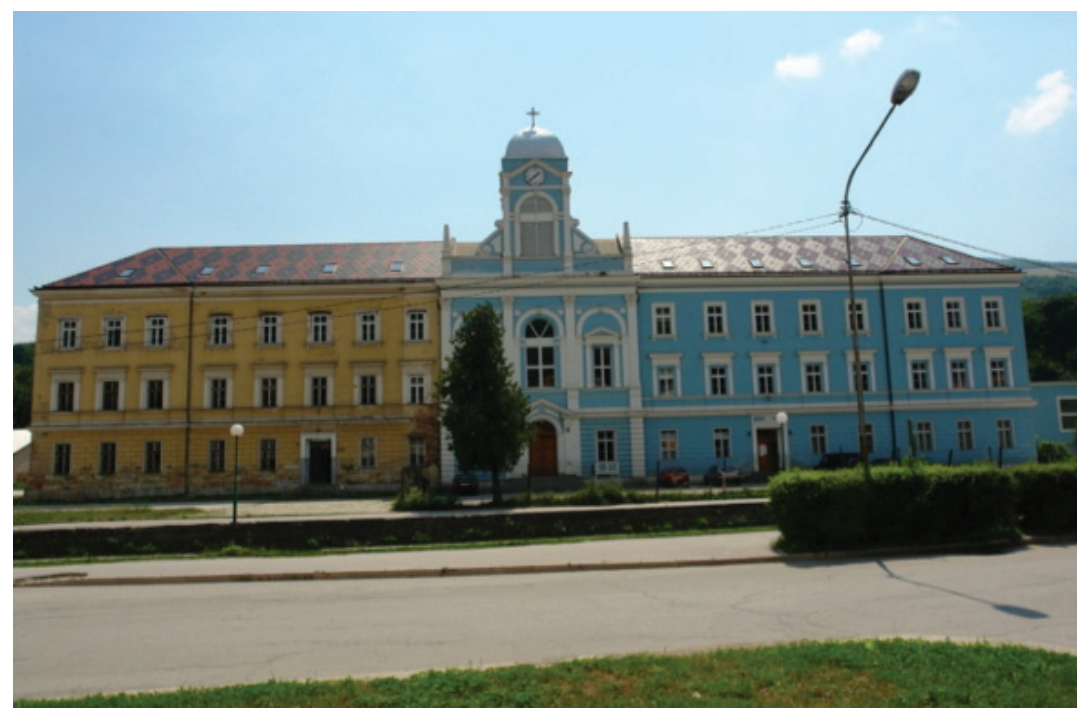

Figure 1. An example of "two schools under one roof" in Travnik, B\&H. Retrieved from https://www.reddit.com/r/europe/comments/9iv99w/ an_example_of_two_schools_under_one_roof_in/.

According to Čustović (2018), there are 54 schools in three cantons that work under this divided system. Even though these schools are deemed unconstitutional, they continue to operate.

In both entities and in the Brčko District, the number of students enrolled in primary schools is continuously decreasing, with some fluctuations (Agency for Statistics of Bosnia and Herzegovina, 2017). According to a report by the Federal Ministry of Education and Science (2017), the number of primary school students in the 2017/18 school year was 5.61 percent lower than in the 2013/14 school year.

\section{Secondary Education}

Secondary school lasts for three or four years and corresponds to the ISCED's Upper Secondary Education (level 3). Secondary schools are of a general (grammar school/gimnazija, art school or religious school, duration four years) or vocational type (technical, medical, etc., duration of three or four years), and are organised as public or private institutions. 
According to Haskić (2015), there is no specific data or official register of the number of private primary and secondary schools in Bosnia and Herzegovina, but research suggests the existence of 11 primary and 36 secondary private schools, including centres for additional training. There are also combined primary and secondary schools: 15 public schools owned by different religious communities.

Secondary education is not compulsory, which may be why the changes are slowest in this sector (Ibrahimović, 2015). There are secondary schools operating in accordance with international standards (United World College Mostar, the IB programme in Druga gimnazija Sarajevo, the Cambridge International School programme in Prva bošnjačka gimnazija Sarajevo), but these are not affordable for all students due to their tuition fees.

A decrease in the number of students in all administrative divisions, and consequently at the national level, is evident at the secondary school level, as well. The number of students in the FB\&H in the 2017/18 school year was 8.38 percent lower than in 2013/14 (Federal Ministry of Education and Science, 2017).

\section{Higher Education}

Higher education is available to anyone who has completed four years of secondary education. It comprises ISCED levels 6-8 (Bachelor, Master and Doctoral study) and is organised in accordance with the Bologna principles. There are eight public universities in Bosnia and Herzegovina ${ }^{6}$ and a number of private higher education institutions. With respect to the duration of the study programmes, universities use two higher education concepts: $4+1+3$ and $3+2+3$, which differ in the duration of the bachelor's degree ( 4 or 3 years; 240 or 180 ECTS points, respectively) and master's programmes ( 1 or 2 years; 60 or 120 ECTS points, respectively). Doctoral studies last for three years and are assigned 180 ECTS points.

The oldest and largest higher education institution in $\mathrm{B} \& \mathrm{H}$ is the University of Sarajevo. Its beginnings date back to 1573, when Gazi Husrev-bey signed the Waqfname (Book of Endowment). The modern history of the university dates back to 1940, just before the Second World War.

While primary and secondary education is free, higher education funding is provided by the government for a limited number of students.

6 University of Sarajevo, University of East Sarajevo, University of Banja Luka, University of Mostar, University Džemal Bijedić Mostar, University of Zenica, University of Bihać, University of Tuzla. 


\section{Chemistry Education}

The main teaching and learning resource for both students and teachers is chemistry textbooks. There are several published chemistry textbooks in $\mathrm{B} \& \mathrm{H}$. The responsible ministry recommends the textbooks each school year, and teachers choose the one that best suits their students. There is, however, an evident lack of teaching resources, as highlighted by teachers: there are no published manuals or workbooks, so teachers mostly rely on Internet resources or manuals published in the region (Serbia and Croatia).

There are some differences in the number of weekly class hours for most subjects within the domain Science, but not within Chemistry itself. Table 2 presents the number of school hours per week for science-related subjects in primary schools in FB\&H and RS.

Table 2

Overview of the weekly number of class hours for primary school subjects related to chemistry

\begin{tabular}{|c|c|c|c|c|c|c|c|c|c|c|}
\hline \multirow{2}{*}{ School Subject } & \multicolumn{10}{|c|}{ FB\&H } \\
\hline & I & II & III & IV & v & $\mathrm{VI}$ & VII & VIII & IX & Total \\
\hline My Environment & 2 & 3 & 3 & 3 & & & & & & 11 \\
\hline Science & & & & & 2 & & & & & 2 \\
\hline Biology & & & & & & 1 & 2 & 1 & 2 & 6 \\
\hline Physics & & & & & & & 1 & 2 & 2 & 5 \\
\hline Chemistry & & & & & & & & 2 & 2 & 4 \\
\hline \multirow{2}{*}{ School Subject } & \multicolumn{10}{|c|}{ RS } \\
\hline & I & II & III & IV & V & VI & VII & VIII & IX & Total \\
\hline My Environment & 5 & & & & & & & & & 5 \\
\hline Science and Society & & 2 & 2 & 2 & & & & & & 6 \\
\hline Science & & & & & 2 & & & & & 2 \\
\hline Biology & & & & & & 2 & 2 & 2 & 2 & 8 \\
\hline Physics & & & & & & & 2 & 2 & 2 & 6 \\
\hline Chemistry & & & & & & & & 2 & 2 & 4 \\
\hline
\end{tabular}

In the first five grades, the number of lessons per week is similar, but with different school subject names. The difference is greater when it comes to the number of lessons per week for biology and physics: primary school students in the RS have two lessons of biology ( $6^{\text {th }}$ grade and $8^{\text {th }}$ grade $)$ and physics ( $7^{\text {th }}$ grade) per week more than their colleagues in the FB\&H. 
Within primary education, students begin to learn about basic science concepts (such as the states of matter: gas, liquid and solid) in the $2^{\text {nd }} / 3^{\text {rd }}$ grade within My Environment/Science and Society. Within Science in the $5^{\text {th }}$ grade, students learn about substances, their states and transitions between states through simple science experiments (such as measuring the temperature of ice, water and boiling water). According to the curricula examined, the first notion of atoms and molecules is scheduled in $7^{\text {th }}$ grade within Physics. Chemistry is taught as a separate school subject in the $8^{\text {th }}$ and $9^{\text {th }}$ grade of primary education.

In the $8^{\text {th }}$ grade, students learn about the development of chemistry, safety precautions in the laboratory, matter and its properties, chemical and physical changes, chemical elements (the periodic table), valence, formulas and bonding. They also learn about chemical reactions and equations, chemical laws and properties of non-metals ${ }^{7}$ (hydrogen, oxygen, nitrogen, sulphur and chlorine), as well as about the types of chemical compounds (oxides, acids, bases and salts).

The $9^{\text {th }}$ grade is characterised by teaching content on metals (sodium, calcium, magnesium, aluminium, iron, copper and gold), their compounds and alloys, corrosion and corrosion protection. After that, students learn about organic chemistry (hydrocarbons, carbohydrates, alcohols, organic acids, fats, oils, soaps, detergents) and biochemistry (amino acids, proteins, polymers). This grade ends with teaching content on ecology and environmental protection.

The Common Core Defined on Learning Outcomes is rather different in its structure than present curricula based on teaching content. The domains, which consist of components, are defined within each school subject. For each component, the learning outcomes are determined, with corresponding indicators reflecting the degree of the achievement of each learning outcome. Indicators are specified according to the development of children at the end of primary (14-15 years) and secondary (18-19 years) school. Four domains are defined for Chemistry, ${ }^{8}$ each composed of four components (Agency for PrePrimary, Primary and Secondary Education, 2017).

In the curriculum for grammar schools (gimnazija), Chemistry is taught in all four years with two hours per week. The exception is Canton Sarajevo, where Chemistry in grammar schools is taught in the first two grades as a mandatory school subject with two hours per week, and in the following two years as part of the elective domain Science with three hours per week. The decreasing number of students and the teachers' experience indicate a lack of interest in this domain among students.

7 Teaching content on selected non-metals (nitrogen, sulphur and chlorine) in the RS is planned at the beginning of the $9^{\text {th }}$ grade.

8 Domains within Chemistry: Substances, The Structure and Functional Connection of Processes in Nature, Processes and Interactions between Living and Non-Living Systems, The Structure of Substances and Energy. 
Chemistry education at the university level started in 1950 within one of the eight subject areas at the Faculty of Philosophy. Instruction took place in Gazi Husrev-bey Madrasah's building. ${ }^{9}$ The Department of Chemistry became part of the newly founded Faculty of Science in 1960.

Bosnia and Herzegovina signed the Bologna declaration in September 2003. This model of the study was then introduced at universities in different academic years. Universities are autonomous in making their study programmes, which need to be verified by the corresponding ministry.

The education of future chemistry teachers is organised at six public universities. ${ }^{10}$ Five of them provide $1^{\text {st }}$ and $2^{\text {nd }}$ cycle chemistry education study programmes (Table 3 ), while the University of Mostar provides only the $2^{\text {nd }}$ cycle after completion of the $1^{\text {st }}$ cycle Chemistry study programme. It is also the only university that provides two-subject studies, where Chemistry can be combined with Biology, Physics or IT.

The only institution in the country that provides a doctoral study programme in chemistry education is the University of Sarajevo, within the framework of the joint doctoral study programme Science and Mathematics Education, which includes Chemistry Education.

Table 3

Overview of chemistry education study programmes at universities in B\&H with respect to the ECTS credits of the relevant courses

\begin{tabular}{|c|c|c|c|c|c|}
\hline \multirow[b]{2}{*}{ Institution } & \multirow[b]{2}{*}{ Study Programme } & \multicolumn{2}{|c|}{$1^{\text {st }}$ cycle } & \multicolumn{2}{|c|}{$2^{\text {nd }}$ cycle } \\
\hline & & $\begin{array}{l}\text { General } \\
\text { Education } \\
\text { Courses* }\end{array}$ & $\begin{array}{l}\text { Chemistry } \\
\text { Education } \\
\text { Courses }\end{array}$ & $\begin{array}{l}\text { General } \\
\text { Education } \\
\text { Courses* }\end{array}$ & $\begin{array}{c}\text { Chemistry } \\
\text { Education } \\
\text { Courses }\end{array}$ \\
\hline $\begin{array}{l}\text { University of Sarajevo, } \\
\text { Faculty of Science }\end{array}$ & Chemistry Education & $\begin{array}{l}10 \mathrm{M} \\
3 \mathrm{E}\end{array}$ & $\begin{array}{l}43 \mathrm{M} \\
10 \mathrm{E}\end{array}$ & - & $\begin{array}{l}9 M \\
14 E\end{array}$ \\
\hline \multirow{3}{*}{$\begin{array}{l}\text { University of Mostar, } \\
\text { Faculty of Science and } \\
\text { Education }\end{array}$} & $\begin{array}{l}\text { Biology-Chemistry } \\
\text { Education }\end{array}$ & \multicolumn{2}{|c|}{-} & $12 \mathrm{M}$ & $\begin{array}{l}20 M(B) \\
20 M(C)\end{array}$ \\
\hline & $\begin{array}{l}\text { Chemistry-Physics } \\
\text { Education }\end{array}$ & \multicolumn{2}{|c|}{-} & $\begin{array}{l}12 \mathrm{M} \\
4 \mathrm{E}\end{array}$ & $\begin{array}{l}21 M(C) \\
13 M(P h)\end{array}$ \\
\hline & $\begin{array}{l}\text { Chemistry- } \\
\text { IT Education }\end{array}$ & \multicolumn{2}{|c|}{-} & $15 \mathrm{M}$ & $\begin{array}{l}28 M(C) \\
23 M(I T)\end{array}$ \\
\hline $\begin{array}{l}\text { University Džemal Bijedić } \\
\text { of Mostar, Teachers Faculty }\end{array}$ & Chemistry Education & $\begin{array}{l}12 \mathrm{M} \\
9 \mathrm{E}\end{array}$ & $\begin{array}{l}18 \mathrm{M} \\
11 \mathrm{E}\end{array}$ & \multicolumn{2}{|c|}{ Not provided } \\
\hline $\begin{array}{l}\text { University of East Sarajevo, } \\
\text { Faculty of Technology }\end{array}$ & \multicolumn{5}{|c|}{ No data available on the website** } \\
\hline
\end{tabular}

9 Muslim high school.

10 The Universities of Sarajevo, East Sarajevo, Dzemal Bijedić Mostar, Tuzla and Banja Luka have study programmes in chemistry education. The University of Mostar only provides study programmes that are a combination of chemistry with physics, biology and informatics. 


\begin{tabular}{|c|c|c|c|c|c|}
\hline \multirow[b]{2}{*}{ Institution } & \multirow[b]{2}{*}{ Study Programme } & \multicolumn{2}{|c|}{$1^{\text {st }}$ cycle } & \multicolumn{2}{|c|}{$2^{\text {nd }}$ cycle } \\
\hline & & $\begin{array}{l}\text { General } \\
\text { Education } \\
\text { Courses* }\end{array}$ & $\begin{array}{c}\text { Chemistry } \\
\text { Education } \\
\text { Courses }\end{array}$ & $\begin{array}{l}\text { General } \\
\text { Education } \\
\text { Courses* }\end{array}$ & $\begin{array}{c}\text { Chemistry } \\
\text { Education } \\
\text { Courses }\end{array}$ \\
\hline $\begin{array}{l}\text { University of Tuzla, Faculty } \\
\text { of Science }\end{array}$ & Chemistry Education & $\begin{array}{l}6 \mathrm{M} \\
6 \mathrm{E}\end{array}$ & $\begin{array}{l}27 \mathrm{M} \\
6 \mathrm{E}\end{array}$ & - & $6 \mathrm{M}$ \\
\hline $\begin{array}{l}\text { University of Banja Luka, } \\
\text { Faculty of Science }\end{array}$ & Chemistry Education & $12 M$ & $\begin{array}{l}19 \mathrm{M} \\
12 \mathrm{E}\end{array}$ & - & $5 \mathrm{E}$ \\
\hline
\end{tabular}

Note. $\mathrm{M}=$ mandatory courses; $\mathrm{E}=$ elective courses; $\mathrm{B}=$ Biology; $\mathrm{C}=$ Chemistry; $\mathrm{Ph}=$ Physics; $\mathrm{IT}=$ Information Technologies.

*General courses refer to courses in the scientific fields of general pedagogy, psychology and didactics. **According to the University of East Sarajevo website (https://www.ues.rs.ba/en/faculty-of-technology/), the study programme (1st cycle) Chemistry, with the diploma "Graduate Chemistry Professor", is carried out at the Faculty of Technology.

It should be noted that for most universities only the number of ECTS points is provided (along with the number of lessons per week and information as to whether the course is compulsory or elective), while the programme of the specific courses is unavailable (with the exception of the University of Sarajevo). Therefore, the title of the course was the only factor in determining whether the course falls into the category of a general or chemistry (biology/ physics/IT) education course.

According to the EU Teacher Education Standard, the minimum number of ECTS points for Teaching Competency courses in the $1^{\text {st }}$ and $2^{\text {nd }}$ cycle is 60 ( 5 years, a total 300 ECTS) (Boban \& Perić, 2015). As shown in Table 3, the Chemistry Education study programme at the University of Sarajevo fully meets this criterion, with a total of 62 ECTS points for compulsory teaching competence courses. The University of Mostar fulfils this criterion with the Chemistry/IT Education programme.

More recently, some efforts have been made toward introducing an integrated study programme for teachers at the University of Sarajevo. The authors of the present paper have participated in making the proposed curriculum for chemistry teachers, which contains courses from the $\mathrm{PPDM}^{\mathrm{11}}$ group in a total of 73 ECTS. Its introduction is planned for the 2019/2020 academic year.

Štrbo and Sabljica (2011) analysed the perspectives of chemistry education at the University of Sarajevo, as well as students' attitudes toward the vocation of chemistry teacher after the completing the faculty. They emphasised a negative trend in the number of students graduating from the Chemistry Education study programme. Students are given the opportunity to change their field of the study, which results in a decrease of the number of students in the $3^{\text {rd }}$ year of study compared to the $1^{\text {st }}$ year, and, consequently, in a low number of graduate chemistry teachers.

11 PPDM - Psychology, Pedagogy, Didactic and Teaching Methods. 
Among students (and the public), a negative image of the teaching profession prevails: students believe that a person is more appreciated when he/ she graduates in Chemistry, that chemistry teachers have lower salaries than chemists with the same level of education, and that primary and secondary school students are not motivated to learn chemistry, thus making the teaching process more difficult (Štrbo \& Sabljica, 2011).

\section{Who can teach chemistry?}

In primary schools, a significant number of teachers who have graduated from two-year study programmes at pedagogical academies or faculties of science implemented before the introduction of the Bologna principles are still employed. These study programmes included a combination of Chemistry with Biology, Physics or Home Economics.

In secondary schools, graduate students of chemical education, as well as chemical engineers (with appropriate training in pedagogy, psychology, didactic and teaching methods), may teach chemistry. After Bologna, students who have completed both the $1^{\text {st }}$ and $2^{\text {nd }}$ cycles of study are employable in both primary and secondary schools. This refers to both masters of chemistry education and masters of chemistry. This was common practice even before the Bologna study programmes.

In order to be considered for employment in school, masters of chemistry/chemistry engineers must complete and pass pedagogical training. This training contains a core of general pedagogy, psychology, didactics and teaching methodology, and is organised at various public as well as private higher education institutions. However, its quality is rather questionable and, more importantly, it does not generally contain didactical and methodological content that is specific to chemistry or teaching practice in chemistry at school. The fact that graduate chemistry teachers do not have priority in employment is a growing problem. It leads students to believe that they will have more opportunities for employment if they complete a Chemistry study programme; even if they "have to" work at school, they can complete the required pedagogical training afterwards. This results in a low level of interest in chemistry education study programmes; the teaching profession is simply not so attractive.

Another problem is the lack of chemistry teaching hours per week compared to the "norm" (the number of hours per week that teachers need to teach in order to receive a full salary). It is therefore common for teachers to teach in two or even three schools, and/or to teach other courses (such as Home Economics at the primary school level). It appears that this is one of the major 
obstacles to good chemistry teaching at the primary school level, in addition to poorly and inadequately equipped classrooms for practical work and the increased administrative requirements that teachers need to perform.

\section{Chemistry Education Research in B\&H}

Based on an examination of bibliographies of university professors who teach courses in the field of chemistry education, available on the websites of their institutions and on Google Scholar ${ }^{\natural}$, we can conclude that chemistry education research in our country is underrepresented. The examined bibliographies indicate that these researchers mainly focus on other domains, and that courses in chemistry education are mostly supplemental to their primary scientific field. There is little interest in research into chemistry education, which is predominantly conducted by academic staff at universities who are also highly engaged in the teaching process and therefore rather busy and preoccupied.

Chemistry education research conducted at the University of Sarajevo is focused on examining the relevant (mostly domestic) issues in primary, secondary and tertiary chemistry education, grouped into several categories:

(1) Problems of experimental work in chemistry teaching. This research, conducted among students and teachers and accompanied by several workshops, resulted in more than 60 experiments optimised for the primary and secondary school level (e.g., Muštović, Zejnilagić-Hajrić, \& Milićević, 2003; Zejnilagić-Hajrić, 2006, 2009a, 2009b; ZejnilagićHajrić, Ljubijankić, Čopra-Janićijević, Vidic, \& Nuić, 2016).

(2) Integrating knowledge in chemistry, physics and physical chemistry for university students. Students' difficulties observed during university courses, their origins and causes, as well as potential solutions, were examined, giving rise to a number of issues that need to be addressed (e.g., Gojak, Galijašević, Hadžibegović, Zejnilagić-Hajrić, Nuić, \& Korać, 2012; Gojak-Salimović, Korać, Zejnilagić-Hajrić, \& Nuić, 2018; Hadžibegović, Zejnilagić-Hajrić, Galijašević, \& Nuić, 2012; Nuić, Zejnilagić-Hajrić, Hadžibegović, \& Galijašević, 2011).

(3) The effectiveness of web-based learning material in primary school chemistry for the integration the macroscopic and submicroscopic levels. The idea for this research, which deals with examining sources of difficulties at the level of primary school, arose from the findings of a study on integrating knowledge (e.g., Nuić \& Glažar, 2015, 2016, 2017).

(4) Testing the use and applicability of various teaching methods in B\&H schools (e.g., problem-based learning, inquiry-based 
learning, pre-learning strategy) (e.g., Smerdel \& Zejnilagić-Hajrić, 2018; Zejnilagić-Hajrić, Delić, \& Nuić, 2015; Zejnilagić-Hajrić \& Nuić, 2015; Zejnilagić-Hajrić, Šabeta, \& Nuić, 2015).

Papers dealing with educational issues are published in domestic journals such as The Bulletin of Chemists and Technologists of Bosnia and Herzegovina, Naša škola and Didaktički putokazi. The latter two journals are written in Bosnian, which makes them more usable for teachers.

Several domestic scientific projects and studies are also being conducted at this university. They deal with enhancing learning and education at the primary and secondary school level, integrating STEM content into primary and secondary schools, advancements in the teaching profession, understanding the multi-level of chemistry, etc.

\section{Conclusion/Final Remarks}

Many developed countries have an efficient education system thanks to their stability and economic growth. Generally speaking, education in our country is an instrument creating three educational frameworks that deepen the separation based on ethnicity, culture and history (Čustović, 2018). With regard to Chemistry, the syllabuses produced after 1992 were mostly based on those from the SFRY. Although there are some subtle differences between the curricula, the similarities exceed the differences. While some schools have a certain degree of flexibility, programmes and structures are relatively uniform.

Today, we face many challenges in our country. On the one hand, there are efforts to modernise education through curriculum reform, focusing on learning outcomes and the application of knowledge. On the other hand, the resistance of the present system, with political disagreements and a lack of will among the responsible structures, make any change rather difficult, if not impossible. As a consequence, there is a decrease in the number of students due to the fact that many teachers cannot receive full salaries and have to teach in several schools (up to three). This affects their motivation to innovate in their teaching and to work on their own professional development. Our politicians still prefer to talk about past events than about enhancing the progress of industry, the economy and education.

In order to have competent men and women to achieve the stability of the country in every field, we must first address our education system. We believe that the teaching profession should be more appreciated by government institutions, as well as by individuals. Our efforts should therefore be directed 
towards common issues that we face in every part of the country, instead of focusing on differences. With regard to chemistry education, we need to work together and to unite our potentials in order to improve the current status. The Common Core Defined on Learning Outcomes, which is accepted throughout the entire country, shows that we are able to work together and that we all have the same interests.

It should be noted that the authors of the present paper live in Sarajevo Canton $(\mathrm{FB} \& \mathrm{H})$, so the paper may not fully reflect events in other cantons, the RS entity or the Brčko District, due to the limitations of the available data.

\section{References}

Agency for Pre-Primary, Primary and Secondary Education. (2015). Smjernice za provedbu zajedničke jezgre nastavnih planova i programa definirane na ishodima učenja [Guidelines for the implementation of common core defined on learning outcomes]. Mostar: APOSO.

Agency for Pre-Primary, Primary and Secondary Education. (2017). Zajednička jezgra nastavnih planova i programa za kemiju definirana na ishodima učenja [Common core defined on learning outcomes]. Mostar: APOSO.

Agency for Statistics of Bosnia and Herzegovina. (nd). Demografija i socijalne statistike: Obrazovanje [Demography and social statistics: Education]. Retrieved from http://www.bhas.ba/index. php?option=com_publikacija\&view=publikacija_pregled\&ids $=1 \&$ id $=21 \& n=$ Obrazovanje Agency for Statistics of Bosnia and Herzegovina. (2017). Statistika obrazovanja od kraja 2013/2014 do početka 2017/2018 školske godine [Education statistics from the end of the 2013/2014 school year to the beginning of the 2017/2018 school year]. No. 16 (12). Retrieved from http://www.bhas.ba/ publikacijebd/BRC_2017_oo1_EDU.pdf

Boban, L., \& Perić, I. (2015). Priručnik o stjecanju nastavničkih kompetencija tijekom redovitoga studija [A handbook on acquiring teaching competences during full-time study]. Mostar: Filozofski fakultet, Sveučilište u Mostaru.

Čustović, Z. (2018, December 27). Segregation, education and nationalism: Two schools under one roof system in Bosnia and Herzegovina. Retrieved from https://politheor.net/segregation-education-andnationalism-two-schools-under-one-roof-system-in-bosnia-and-herzegovina-2/ Drobac, M., Hadžić-Krnetić, A., Mikanović, B., \& Zečević, I. (2013). Analiza ishoda osnovnog obrazovanja prema Blumovoj taksonomiji i SMART sistemu [Primary school curriculum and educational aims]. Savremeni trendovi u psihologiji, 2013, 137-138. Retrieved from http://psihologija. ff.uns.ac.rs/repository/clanak.php?sifra=stup2013097

Faculty of Science and Education, University of Mostar. (2018). Nastavni plan Informatika i kemija diplomski studij [Curriculum of informatics and chemistry - graduate study programme]. Retrieved from http://fpmoz.sve-mo.ba/index.php?option=com_content\&view=category \&layout=blog \&id=16\&Itemid=124\&lang=hr\# 
Faculty of Science and Education, University of Mostar. (2018). Nastavni plan Kemija i fizika diplomski studij [Curriculum of chemistry and physics - graduate study programme]. Retrieved from http://fpmoz.sve-mo.ba/index.php?option=com_content\&view=category\&layout= blog\&id=16\&Itemid=124\&lang=hr\# Faculty of Science and Education, University of Mostar. (2018). Nastavni plan Biologija i Kemija diplomski studij [Curriculum of biology and chemistry - graduate study programme]. Retrieved from http://fpmoz.sve-mo.ba/index.php?option=com_content\&view=category \&layout=blog\&id=18\&Ite mid=126\&lang=hr\#

Federal Ministry of Education and Science (2017). Informacija o upisu učenika u osnovne i srednje škole u školskoj 2017/18. godini u Federaciji Bosne i Hercegovine [Information on the enrolment of primary and secondary school pupils in the 2017/18 school year in the Federation of Bosnia and Herzegovina]. Mostar: Federal Ministry of Education and Science. Retrieved from http://fmon.gov. ba/Upload/Dokumenti/53aec45o-e5oe-424c-a3f7-e856b82fo775_Informacija\%200\%2oupisu\%20 ucenika\%2oskolska\%202017\%2018\%2ogodina.pdf

Fejzić, A., Čolić, N., Veličković, N., Rangelov-Jusović, R., Bogunić, Z., \& Ibrahimović, N. (2011). Analiza nastavnog plana i programa za devetogodišnje osnovno obrazovanje [Analysis of a curriculum for nine-year primary education]. Sarajevo: Ministarstvo obrazovanja i nauke Kantona Sarajevo.

Retrieved from https://skolegijum.ba/static/files/pdf/docs/4ecb75813e897.pdf

Gojak, S., Galijašević, S., Hadžibegović, Z., Zejnilagić-Hajrić, M., Nuić, I., \& Korać, F. (2012). Integrated knowledge of physics and chemistry: Case of physical chemistry course. Bulletin of the Chemists and Technologists of Bosnia and Herzegovina, 38, 43-51.

Gojak-Salimović, S., Korać, F., Zejnilagić-Hajrić, M., \& Nuić, I. (2018). Physical chemistry for undergraduate students: Integrating knowledge from mathematics, physics, and chemistry. Bulletin of the Chemists and Technologists of Bosnia and Herzegovina 51, 35-40.

Hadžibegović, Z., Zejnilagić-Hajrić, M., Galijašević, S., \& Nuić, I. (2012). Bolonjska reforma studija: analiza efikasnosti studija hemije i fizike na Prirodno - matematičkom fakultetu [The Bologna Reform: An analysis of chemistry and physics study efficiency at the Faculty of Natural Sciences and Mathematics]. Zbornik radova, VI savjetovanje o reformi visokog obrazovanja "Kontinuitet reforme visokog obrazovanja" (pp. 249-263). Sarajevo: Univerzitet u Sarajevu.

Haskić, I. (2015). Privatne škole u Bosni i Hercegovini. [Private schools in Bosnia and Herzegovina]. Sarajevo: Fond otvoreno društvo $\mathrm{BiH}]$. Retrieved from http://www.skolegijum.ba/static/files/ biblioteka/pdf/567c138fo2c25_privatneskoleubosniihercegovini. pdf Ibrahimović, N. (2015). Osnovnoškolsko i srednjoškolsko obrazovanje u BiH: Trenutno stanje i preporuke za reforme [Primary and secondary education in Bosnia and Herzegovina: The current state and recommendations for reforms]. Sarajevo: Inicijativa za monitoring evropskih integracija $\mathrm{BiH}$. Retrieved from http://eu-monitoring.ba/namir-ibrahimovic-osnovnoskolsko-i-srednjoskolskoobrazovanje-u-bih-trenutno-stanje-i-preporuke-za-reforme Malcolm, N. (1994). Bosnia: A Short History. New York, NY: New York University Press. Ministarstvo prosvjete i kulture Republike Srpske, Republički pedagoški zavod (2014). Nastavni plan 
i program za osnovno obrazovanje i vaspitanje [Curriculum for primary education]. Istočno Sarajevo:

Zavod za udžbenike i nastavna sredstva.

Ministarstvo za obrazovanje, nauku i mlade Kantona Sarajevo. (2016). Nastavni plan i program

Osnovna škola Predmet Hemija/kemija [Curriculum for primary education, the subject of chemistry].

Retrieved from https://mon.ks.gov.ba/sites/mon.ks.gov.ba/files/hemija.pdf

Ministry of Civil Affairs of Bosnia and Herzegovina. (2017). Osnovne informacije o obrazovanju u

$\mathrm{BiH}$ [Basic information on education in Bosnia and Herzegovina]. Retrieved from http://www.mcp.

gov.ba/org_jedinice/sektor_obrazovanje/Osnovne_informacije/default.aspx?id=858o\&langTag=bs-

BA

Muštović, F., Zejnilagić-Hajrić, M., \& Milićević, V. (2003). Education of chemistry teachers at Sarajevo University. Book of Abstracts: 7th European Congress for Chemistry Teaching (pp. 1-9). Linz, Austria.

Nuić, I., \& Glažar, S. A. (2017). Percepcije učenika o uporabi mrežno potpomognutih materijala za poučavanje osnovnih kemijskih pojmova [Students' perceptions on the use of web-based learning material for teaching fundamental chemical concepts]. Kemija $u$ industriji, 66(7-8), 411-416. doi: 10.15255/KUI.2016.037

Nuić, I., \& Glažar, S. A. (2016). Integration of macroscopic and submicroscopic level for understanding fundamental chemical concepts using web-based learning material. In J. Lavonen, K. Juuti, J. Lampiselkä, A. Uitto \& K. Hahl (Eds), Electronic Proceedings of the ESERA 2015 Conference. Science Education Research: Engaging learners for a sustainable future, Part 1, Strand 1 (pp. 65-71) (coed. O. Finlayson \& R. Pinto). Helsinki: University of Helsinki.

Nuić, I., \& Glažar, S. A. (2015). Application of web-based learning material for teaching states of matter in $8^{\text {th }}$ grade primary school chemistry - A pilot study results. Bulletin of the Chemists and Technologists of Bosnia and Herzegovina, 45, 43-50.

Nuić, I., Zejnilagić-Hajrić, M., Hadžibegović, Z., \& Galijašević, S. (2011). Konceptualne poteškoće i načini rješavanja uočenih problema studenata kemije na Prirodno-matematičkom fakultetu Sarajevo [Conceptual difficulties and models of solving observed problems with chemistry students at the Faculty of Natural Sciences and Mathematics]. Zbornik radova: V Savjetovanje Reforma visokog obrazovanja „Daljnji trendovi reforme visokog obrazovanja po Bolonjskim principima“(pp. 275-285). Sarajevo: Univerzitet u Sarajevu.

Prirodno-matematički fakultet, Univerzitet u Banjoj Luci (2016). Hemija: Nastavni smjer 2016 [Chemistry: chemistry education 2016]. Retrieved from http://pmf.unibl.org/hemija-nastavni-2016/ Radušić, E., Katz, V., Smiljanić, A., Dangubić, V., Fazlagić, E., \& Filipović, O., et al. (2010). Parlamentarna skupština Bosne i Hercegovine [The Parliamentary Assembly of Bosnia and Herzegovina]. Sarajevo: Parlamentarna skupština Bosne i Hercegovine. Retrieved from https://www. parlament.ba/data/dokumenti/pdf/MonografijaBs.pdf Republika Srpska, Republički zavod za statistiku. (nd). Statistika obrazovanja: Saopštenja [Education statistics: Press releases]. Retrieved from http://www.rzs.rs.ba/front/category/12/198/?\&add=None Smerdel, S., \& Zejnilagić-Hajrić, M. (2018). The use of chemistry learning materials within the 
pre-learning strategy: Findings from a teachers' survey. Bulletin of the Chemists and Technologists of Bosnia and Herzegovina, 51, 19-23.

Štrbo, F., \& Sabljica, L. (2011). Perspektive hemije u obrazovanju: Problem izbora nastavničkog poziva na Prirodno-matematičkom fakultetu [Perspectives of chemistry education: the problem of selecting a chemistry teaching major at the Faculty of Science]. Zbornik radova: V Savjetovanje Reforma visokog obrazovanja "Daljnji trendovi reforme visokog obrazovanja po Bolonjskim principima" (pp. 275-285). Sarajevo: Univerzitet u Sarajevu.

Teachers Faculty, University Džemal Bijedić of Mostar. (2014). Plan studijskog programa - Bachelor hemije. [Curriculum - Bachelor of Chemistry]. Retrieved from https://nf.unmo.ba/studij/i-ciklus/ hemija.aspx

Teachers Faculty, University Džemal Bijedić of Mostar. (2014). Raspored nastave na I godini diplomskog - master studija Hemije u zimskom semestru akademske 2017/18. godine [Schedule of lectures for the 1st year of master's study of chemistry in the winter semester of the 2017/18 academic year]. Retrieved from https://nf.unmo.ba/studij/ii-ciklus/hemija.aspx

UNESCO Institute for Statistics. (2011). International standard classification of education (ISCED).

Retrieved from http://uis.unesco.org/sites/default/files/documents/international-standardclassification-of-education-isced-2011-en.pdf University of Sarajevo, Faculty of Science. (2016). Studij zajedničkog trećeg ciklusa - Doktorski studij "Prirodne i matematičke nauke u obrazovanju" [Joint third cycle study - Doctoral study "Science and Mathematics in Education"]. Retrieved from http://www.pmf.unsa.ba/hemija/files/III\%2ociklus/ ZDSPMF_2016/Inovirani_Treci_ciklus zajednicki_doktorski_studij_Prirodne_i_matematicke_ nauke_u_obrazovanju.pdf University of Sarajevo, Faculty of Science. (2017). Nastavnički smjer II ciklus [Chemistry Education $-2^{\text {nd }}$ cycle]. Retrieved from http://www.pmf.unsa.ba/hemija/index.php/bs/studijski-programi/iiciklus/nastavnicki-smjer/9-uncategorised/785-inovirani-pp-ii-ciklus-nastavnicki-smjer University of Sarajevo, Faculty of Science. (2017). Studijski program I ciklusa Nastavnički smjer [Curriculum for Chemistry Education study programme $-1^{\text {st }}$ cycle]. Retrieved from http://www.pmf. unsa.ba/hemija/index.php/bs/studijski-programi/i-ciklus/nastavnicki-smjer/9-uncategorised/781inovirani-plan-i-program-nastavnicki-smjer-i-ciklus-2 University of Tuzla, Faculty of Science. (2012). II ciklus studija - studijski program: Edukacija u hemiji. [2 ${ }^{\text {nd }}$ cycle - study programme: Chemistry Education]. Retrieved from http://pmf.untz.ba/wpcontent/uploads/2017/o4/Edukacija_u_hemiji.pdf University of Tuzla, Faculty of Science. (2018). I ciklus studija - studijski program: Hemija $\left[1^{\text {st }}\right.$ cycle - study programme: Chemistry]. Retrieved from http://pmf.untz.ba/wpcontent/uploads/2018/o6/ StudijskiProgramHemija.pdf Zejnilagić-Hajrić, M., Delić, E., \& Nuić, I. (2015). Students with disabilities and chemistry education: Possibilities and difficulties. Bulletin of the Chemists and Technologists of Bosnia and Herzegovina, 44, $65-70$.

Zejnilagić-Hajrić, M., \& Nuić, I. (2015). Demonstration in teaching chemistry: The case of two high- 
schools from Sarajevo Canton, Celar Bayar University Journal of Science, 11(3), pp. 325-328.

Zejnilagić-Hajrić, M., Šabeta, A., \& Nuić, I. (2015). The effects of problem-based learning on students' achievements in primary school chemistry. Bulletin of the Chemists and Technologists of Bosnia and Herzegovina, 44, 17-22.

Zejnilagić-Hajrić, M., Ljubijankić, N., Čopra-Janićijević, A., Vidic, D., \& Nuić, I. (2016). Praktikum iz metodike nastave hemije [Practicum of teaching chemistry]. Sarajevo: Univerzitet u Sarajevu.

Zejnilagić-Hajrić, M. (2009a). Model nastavne pripreme za VIII razred osnovne škole - Proteini [A model of the teaching topic - Proteins]. Hemijski Pregled, 50(6), 159-162.

Zejnilagić-Hajrić, M. (2009b). Potreba za edukacijom i permanentnim stručnim usavršavanjem nastavnika [The need for education and the permanent professional training of teachers]. Naša škola-Časopis za teoriju i praksu odgoja i obrazovanja, 5o(220), 83-86.

Zejnilagić-Hajrić, M. (2006). Experimental work in chemistry teaching. Workshop UWC-IBO, United World Colleges - International Baccalaureate Organization. Mostar: UWC-IBO Initiative in Bosnia and Herzegovina.

\section{Biographical note}

Meliha Zejnilagić-HajRić, $\mathrm{PhD}$, is a full professor in the field of chemistry education at Faculty of Science University of Sarajevo, Bosnia and Herzegovina. Her main areas of research include active methods in chemistry education, didactic of chemistry, methodology of scientific and professional research.

INES NuIć, PhD, is an assistant professor in the field of chemistry education at the Faculty of Science at University of Sarajevo, Bosnia and Herzegovina. Her research interests include misconceptions in chemistry, e-learning in chemistry, active methods in chemistry education. 